\title{
RESRAD-OFFSITE - A new member of the RESRAD family of codes
}

\author{
C. $\mathrm{Yu}^{1}$, E. Gnanapragasam ${ }^{1}$, B. Biwer ${ }^{1}$, J.-J. Cheng ${ }^{1}$, S. Kamboj ${ }^{1}$, T. Klett ${ }^{1}$, \\ A. Zielen ${ }^{1}$, W.A. Williams ${ }^{2}$, S. Domotor ${ }^{2}$ and A. Wallo ${ }^{2}$ \\ ${ }^{1}$ Argonne National Laboratory, Bldg. 900, 9700 South Cass Avenue, IL 60439 Argonne, USA \\ ${ }^{2}$ U.S. Department of Energy, Washington, DC, USA
}

\begin{abstract}
The RESRAD-OFFSITE code provides expanded state-of-the art, cost-effective, and userfriendly methods for evaluating the radiological consequences to a receptor located onsite or outside the area of primary contamination. It calculates radiological dose and excess lifetime cancer risk with the predicted radionuclide concentrations in the environment, and derives soil cleanup guidelines corresponding to a specified dose limit. The RESRAD-OFFSITE code is an extension of the RESRAD (onsite) code, which has been widely used for calculating doses and risks from exposure to radioactively contaminated soils. The development of RESRAD-OFFSITE started more than 10 years ago, but new models and methodologies have been developed, tested, and incorporated since then. Some of the new models have been benchmarked against other independently developed (international) models. The databases used have also expanded to include all the radionuclides (more than 830) contained in the International Commission on Radiological Protection (ICRP) 38 database. Detailed information on the design and application of the RESRADOFFSITE code is presented in its recently published User's Manual.
\end{abstract}

\section{INTRODUCTION}

The RESRAD-OFFSITE code [1] is an extension of the original RESRAD code, which has been widely used for calculating doses and risks from exposure to radioactively contaminated soils. The development of RESRAD-OFFSITE started more than 10 years ago, but new models and methodologies have been developed, tested, and incorporated since then. Some of the new models have been benchmarked against other independently developed (international) models. The databases used now have also expanded to include all of the radionuclides (more than 830) contained in the International Commission on Radiological Protection (ICRP) 38 database. Detailed information on the design and application of the RESRAD-OFFSITE code is presented in its User's Manual for RESRAD-OFFSITE Version 2 [1]. To prevent potential confusion of these two code names, the "original" RESRAD code is denoted as RESRAD (onsite), where appropriate, although RESRAD-OFFSITE can model both onsite and offsite receptors as discussed later in this report.

\section{COMPARISON OF RESRAD (ONSITE) AND RESRAD-OFFSITE}

The RESRAD (onsite) computer code evaluates the radiological dose and excess cancer risk to an individual who is exposed while residing and/or working in an area where the soil is contaminated with radionuclides [2]. RESRAD was developed by Argonne National Laboratory in the 1980s and has been widely used to perform assessments of contaminated sites since its release in 1989. Since then, the RESRAD (onsite) code has undergone continuous improvement in response to feedback from users and sponsors. The RESRAD team has participated in many national and international model intercomparison studies in which both hypothetical and actual contaminated site-based scenarios were analyzed using RESRAD (onsite). The evolution of the RESRAD-OFFSITE code from RESRAD (onsite) began in the 1990s during the Biosphere Modeling Validation Study II (BIOMOVS II), in which models were compared [3]. 
The RESRAD-OFFSITE code was first formed by the addition of an offsite soil accumulation submodel [4] to the basic RESRAD (onsite) code and then by the inclusion of an advective-dispersive groundwater transport submodel [5]. The ability to accept a time series for the release from the contaminated soil was also added during this study. During the multimedia model comparison study, the advective-dispersive groundwater transport submodel was improved to better predict the transport of progeny produced in transit during participation in the multimedia model comparison study [6]. Since then, an atmospheric transport submodel and a surface water body accumulation submodel have been added. Many of the submodels in RESRAD (onsite) were also modified during the addition of these new submodels to RESRAD-OFFSITE. The computational algorithm of the RESRAD-OFFSITE code also changed from that of RESRAD (onsite). While RESRAD (onsite) numerically evaluates the analytical expressions for concentration, dose, and risk at any desired time since the site survey, RESRAD-OFFSITE uses numerical methods to compute the concentration, dose, and risk progressively over time.

The RESRAD-OFFSITE computer code evaluates the radiological dose and excess cancer risk to an individual who is exposed while located within or outside the area of initial (primary) contamination. The primary contamination, which is the source of all the releases modeled by the code, is assumed to be a layer of soil. The releases of contaminants from the primary contamination to the atmosphere, to surface runoff, and to groundwater are considered. The code models the movement of the contaminants from the primary contamination to agricultural areas, pastures, a dwelling area, a well, and a surface water body. It also models the accumulation of the contaminants at those locations where appropriate. Any contribution of the contaminants from the water sources to the land-based locations is also modeled. As shown in Figure 1, the water sources and the land-based locations can be outside the boundary of the primary contamination (offsite). These locations are referred to as offsite locations in RESRADOFFSITE.

Nine exposure pathways are considered in RESRAD-OFFSITE: direct exposure from contamination in soil, inhalation of particulates, inhalation of radon, ingestion of plant food (i.e., vegetables, grain, and fruits), ingestion of meat, ingestion of milk, ingestion of aquatic foods, ingestion of water, and ingestion (incidental) of soil.

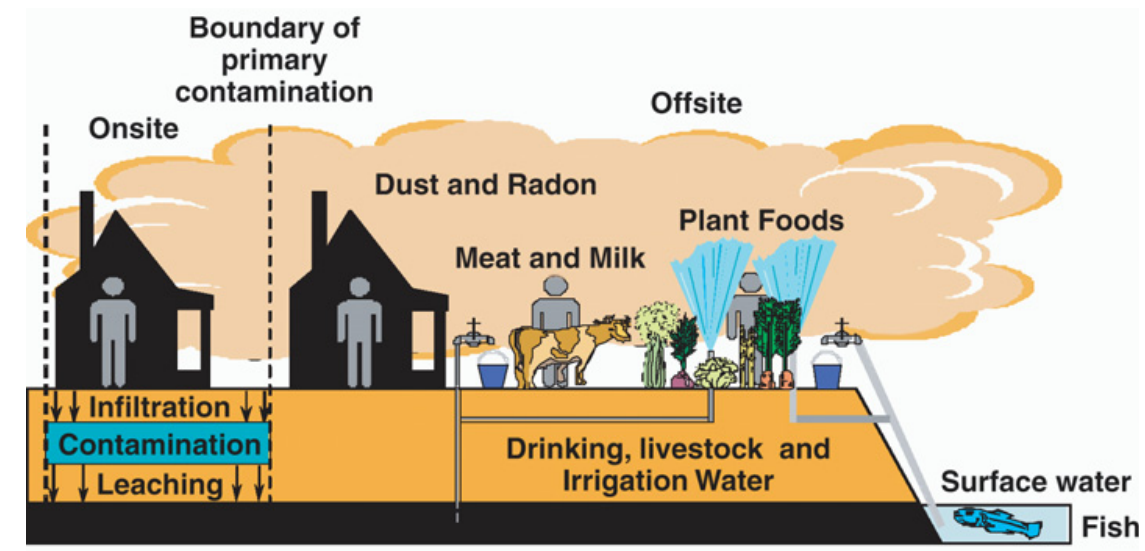

Figure 1. Locations of primary and secondary contamination in RESRAD-OFFSITE.

\subsection{Same or similar submodels in RESRAD (onsite) and RESRAD-OFFSITE}

\subsubsection{Groundwater release submodel}

The release to groundwater is the only release that RESRAD (onsite) explicitly considers. This is a first-order release model in which the flux of radionuclides released to the infiltrating water at any time 
is in direct proportion to the radionuclide inventory in the contaminated soil at that time. The same model was retained in RESRAD-OFFSITE, although the radionuclide inventory at any time is adjusted differently because of the modifications to the surface soil mixing submodel.

\subsubsection{Surface soil mixing submodel}

The surface soil mixing submodel in RESRAD (onsite) ignores the contaminants that were removed by erosion of the initially uncontaminated mixing zone. Although this model is appropriate for RESRAD (onsite) because that code does not address the surface soil release to offsite locations, it is not suitable for RESRAD-OFFSITE, which models the accumulation of the eroded material in a surface water body and offsite soils. The new model in RESRAD-OFFSITE maintains a mass balance of contaminants.

\subsubsection{Dust release model}

Although RESRAD (onsite) does not explicitly model a release to the atmosphere, it does model the effects of a dust release (inhalation, foliar deposition) by using the concept of a mass loading factor. In RESRAD-OFFSITE, this concept has been extended to provide a release to the atmospheric transport model.

\subsubsection{Exposure models}

All the exposure models in RESRAD (onsite) - direct external radiation; inhalation of dust and radon; and ingestion of vegetables, meat, milk, aquatic food, and soil - were retained in RESRAD-OFFSITE, with minor changes. In RESRAD-OFFSITE, the exposure models are applied at more locations (e.g., offsite agricultural and farmed areas that are contaminated by irrigation and deposition of contaminated dust) than they are in RESRAD (onsite), and with more contamination pathways. The exposure models were changed to accommodate the numerical nature of the RESRAD-OFFSITE code and to facilitate their application to the offsite locations.

\subsubsection{Advective groundwater transport model}

The groundwater transport model in RESRAD (onsite) considers the effects of the different transport rates of the progeny nuclides that are produced in transit. The option of using the advective groundwater transport model was retained in RESRAD-OFFSITE, but the option of considering the effects of dispersive transport was added. Although the basic concepts are the same for both codes, each code implements them differently. The concentrations of nuclides in well and surface water at any time are expressed analytically in RESRAD (onsite), although these expressions are evaluated numerically. In RESRAD-OFFSITE, the nuclide transport is modeled zone by zone (each unsaturated zone and then the saturated zone) by calculating the flux across each zone progressively over time.

\subsection{Special features in RESRAD-OFFSITE}

\subsubsection{Overriding the source term model}

If all the information that is computed by the RESRAD-OFFSITE source term model is available either from a more sophisticated model or from a series of measurements, the computational code can be flagged to suppress its source term module and to read in the time series of the information. The temporal series of source term and release information has to be in the format that is usable by the RESRADOFFSITE computational code. The information needed to replace the source term model and the format in which it must be specified are described in the User's Manual [1]. 


\subsubsection{Overriding the groundwater transport model}

If the temporal concentration in well water and/or the concentration in the surface water is available either from more sophisticated transport and accumulation models or from a series of measurements, the computational code can be flagged to read in the time series of the concentrations instead of computing them. The format of the file containing the temporal concentrations is similar to the format of the file containing the fluxes discussed in the previous section. This option facilitates the linking of RESRADOFFSITE with other codes.

\subsubsection{Graphical specification of curved flow paths in the saturated zone}

The map interface of RESRAD-OFFSITE allows specification of a two-dimensional (curved) flow path in the saturated zone. As detailed in the User's Manual [1], the semi-analytical groundwater transport model in the saturated zone considers advection in one direction and dispersion in three perpendicular directions. Transport along curved flow paths is modeled by treating them as straight paths of equal length. The interface computes the transport distances based on the locations of the well or surface water body and the shape of the flow path specified in the map interface.

\subsubsection{Probabilistic analysis}

The probabilistic interface of the code allows probabilistic analysis in a sequential fashion. Plots (histogram, cdf, and scatter plots) and statistics of the samples of the inputs can be viewed soon after sampling. This allows the user to check that the probabilistic inputs have been specified correctly before commencing the time-consuming probabilistic runs of the code. When the probabilistic runs are completed, multivariable linear regression can be performed between the inputs and selected outputs. The regression output lists the probabilistic variables in decreasing order of importance.

\subsubsection{Application of RESRAD-OFFSITE}

A number of residential, occupational, and recreational scenarios can be modeled with RESRADOFFSITE by specifying appropriate inputs and by activating the relevant exposure pathways. Some of the many potential scenarios are outlined in the User's Manual [1]. Example scenarios include rural resident farmer, urban resident, office worker, industrial worker, construction worker, outdoorsperson, ballpark player, hunter, and others.

\subsection{Integrated modules in RESRAD-OFFSITE}

Integrated in the RESRAD-OFFSITE computational program are the computational modules for primary contamination (source), atmospheric transport, groundwater transport, offsite accumulation, and exposure; the input modules to process the information from the user interface and to manage the single parameter sensitivity analysis; the module to generate the text reports; and the probabilistic/uncertainty module.

The models and formulations used in the computational modules are described in detail in the User's Manual [1], which includes a guide to the user interface. RESRAD-OFFSITE has user-friendly interface that allows users to perform both deterministic and probabilistic analysis. The code incorporates many text and graphic reports to help user interpret the results.

\section{VERIFICATION AND VALIDATION}

The RESRAD-OFFSITE code was developed following the RESRAD program quality assurance (QA) and quality control (QC) procedures. Some components of the code were verified by separately 
developed spreadsheets, or benchmarked against the RESRAD (onsite) code for most of the equations used in the code. As previously indicated, the RESRAD-OFFSITE code is an extension of the RESRAD (onsite) code, and the two codes share the same database and many models and modules. The RESRAD (onsite) code has already been extensively tested, verified, and validated as documented in Chapter 5 of the RESRAD User's Manual [1] and other documents [2, 6-11].

The beta versions of RESRAD-OFFSITE have been in existence for many years, and the code has been tested by users who downloaded it. Many users provided comments that resulted in improvement of the code over the years. Many parameter values used in the RESRAD-OFFSITE code were taken from the RESRAD (onsite) database. These parameters include soil-plant transfer factors, meat and milk transfer factors, bioaccumulation factors, dose conversion factors, decay half-lives, and scenariospecific occupancy factors. The RESRAD (onsite) database is well documented and verified [2, 12, 13].

Argonne recently conducted a benchmarking of RESRAD-OFFSITE and RESRAD (onsite) for an onsite exposure scenario. This study was documented in a report [14]. The results indicated that although there are differences between some models used in the two codes, by adjusting the input parameters, the RESRAD-OFFSITE can reproduce the RESRAD (onsite) results for an onsite exposure scenario.

Additional benchmarking of the RESRAD-OFFSITE code against other peer codes was performed over the past several years. Some of the results were documented in the benchmarking report [14] and in other reports and peer-reviewed articles [3-6]. Currently, RESRAD-OFFSITE code is being used by the International Atomic Energy Agency's Environmental Modelling for Radiation Safety (EMRAS) Naturally Occurring Radioactive Material (NORM) Working Group for testing NORM scenarios. Additional testing and validation of RESRAD-OFFSITE are planned when data sets are available.

\section{CONCLUSIONS}

The RESRAD-OFFSITE code was developed over the past 10 years. It is an extension of the RESRAD (onsite) code. It was developed with flexibility and versatility in mind. It has the capability to model various exposure scenarios and has broad potential applications. The User's Manual [1] describes in detail the new models used in the code, such as the three-dimensional dispersion and two-dimensional (curved) groundwater flow and radionuclide transport model, the Gaussian plume model for atmospheric dispersion, and the deposition model used to estimate the accumulation of radionuclides in offsite locations and in foods. The RESRAD-OFFSITE code has been used for various applications, including sewage sludge dose modeling, NORM dose assessment, and waste disposal facility performance assessment. The code is available at no cost through the RESRAD web site (http://www.evs.anl.gov/resrad) and its users are supported through technical assistance and training workshops.

\section{Acknowledgments}

Work supported by the U.S. Department of Energy, Office of Health, Safety and Security, and Office of Environmental Management, under contract DE-AC02-06CH11357.

\section{References}

[1] C. Yu, E. Gnanapragasam, B.M. Biwer, S. Kamboj, J.-J. Cheng, T. Klett, D. LePoire, A.J. Zielen, S.Y. Chen, W.A. Williams, A. Wallo, S. Domotor, T. Mo and A. Schwatzman, User's Manual for RESRAD-OFFSITE Version 2, ANL/EVS/TM/07-1, DOE/HS-0005, NUREG/CR-6937 (Argonne National Laboratory, Argonne, Illinois, 2007).

[2] C. Yu, A.J. Zielen, J.-J. Cheng, D.J. LePoire, E. Gnanapragasam, S. Kamboj, J. Arnish, A. Wallo III, W.A. Williams and H. Peterson, User's Manual for RESRAD Version 6, ANL/EAD-4 (Argonne National Laboratory, Argonne, Illinois, 2001). 
[3] E. Gnanapragasam and C. Yu, 1997, Analysis of BIOMOVS II Uranium Mill Tailings Scenario 1.07 with the RESRAD Computer Code, ANL/EAD/TM-66 (Argonne National Laboratory, Argonne, Illinois, 1997).

[4] BIOMOVS (Biosphere Model Validation Study) II, Long-Term Contaminant Migration and Impacts from Uranium Mill Tailings-Comparison of Computer Models Using a Hypothetical Dataset, BIOMOVS II Technical Report No. 4, Biosphere Model Validation Study Steering Committee (Swedish Radiation Protection Institute, Stockholm, Sweden, 1995).

[5] BIOMOVS II, Long-Term Contaminant Migration and Impacts from Uranium Mill TailingsComparison of Computer Models Using a Realistic Dataset, BIOMOVS II Technical Report No. 5, Biosphere Model Validation Study Steering Committee (Swedish Radiation Protection Institute, Stockholm, Sweden, 1996).

[6] E.K. Gnanapragasam, C. Yu, G. Whelan, W.B. Mills, J.P. McDonald, C.S. Lew, C.Y. Hung and D. Hoffmeyer, "Comparison of Multimedia Model Predictions for a Contaminant Plume Migration Scenario,” J. Contaminant Hydrology 46 (2000) 17-38.

[7] J.J. Cheng, J.G. Droppo, E.R. Faillace, E.K. Gnanapragasam, R. Johns, G. Laniak, C. Lew, W. Mills, L. Owens, D.L. Strenge, J.F. Sutherland, G. Whelan and C. Yu, Benchmarking Analysis of Three Multimedia Models: RESRAD, MMSOILS, and MEPAS, DOE?ORO-2033 (Oak Ridge National Laboratory, Oak Ridge, Tennessee, 1995).

[8] Halliburton NUS Corporation, Verification of RESRAD, A Code for Implementing Residual Radioactive, Material Guidelines, Version 5.03, HNUS-ARPD-94-174 (Gaithersburg, Maryland, 1994).

[9] W.B. Mills, J.J. Cheng, J.G. Droppo Jr., E.R. Faillace, E.K. Gnanapragasam, R.A. Johns, G.F. Laniak, C.S. Lew, D.L. Strenge, J.F. Sutherland, G. Whelan and C. Yu, "Multimedia benchmarking analysis for three risk assessment models: RESRAD, MMSOILS, MEPAS, Risk Analysis, 17 (1997) 187-201.

[10] G. Whelan, J.P. McDonald, E.K. Gnanapragasam, G.F. Laniak, C.S. Lew, W.B. Mills and C. Yu, "Benchmarking of the saturated-zone module associated with three risk assessment models: RESRAD, MMSOILS, MEPAS," Environmental Engineering and Science 16 (1999a) 67-80.

[11] G. Whelan, J.P. McDonald, E.K. Gnanapragasam, G.F. Laniak, C.S. Lew, W.B. Mills and C. Yu, "Benchmarking of the vadose-zone module associated with three risk assessment models: RESRAD, MMSOILS, MEPAS," Environmental Engineering and Science 16 (1999b) 81-92.

[12] C. Yu, D. LePoire, E. Gnanapragasam, J. Arnish, S. Kamboj, B.M. Biwer, J.-J. Cheng, A. Zielen and S.Y. Chen, Development of Probabilistic RESRAD 6.0 and RESRAD-BUILD 3.0 Computer Codes, NUREG/CR-6697, ANL/EAD/TM-98 (Argonne National Laboratory, Argonne, Illinois, 2000).

[13] C. Yu, D.J. LePoire, J.-J. Cheng, E. Gnanapragasam, S. Kamboj, J. Arnish, B.M. Biwer, A.J. Zielen, W.A. Williams, A. Wallo III and H.T. Peterson, Jr., User's Manual for RESRADBUILD Version 3, ANL/EAD/03-1 (Argonne National Laboratory, Argonne, Illinois, 2003).

[14] C. Yu, E. Gnanapragasam, J.-J. Cheng and B. Biwer, Benchmarking of RESRAD-OFFSITE: Transition from RESRAD (onsite) to RESRAD-OFFSITE and Comparison of RESRADOFFSITE Predictions with Peer Codes, ANL/EVS/TM/0603, DOE/EH-0708 (Argonne National Laboratory, Argonne, Illinois, 2006).

This submitted manuscript has been created by UChicago Argonne, LLC, Operator of Argonne National Laboratory ("Argonne"). Argonne, a U.S. Department of Energy Office of Science laboratory, is operated under Contract No. DEAC02-06CH11357. The U.S. Government retains for itself, and others acting on its behalf, a paid-up nonexclusive, irrevocable worldwide license in said article to reproduce, prepare derivative works, distribute copies to the public, and perform publicly and display publicly, by or on behalf of the Government. 